\title{
Analysis on Supporting Policy of Small and Medium Enterprises of Science and Technology-Taking Hefei of Anhui Province as an Example
}

\author{
Zhenqing Yuan*, Yujie Feng \\ China University of Science and Technology, Hefei, China \\ Email: *1365774702@qq.com
}

How to cite this paper: Yuan, Z.Q. and Feng, Y.J. (2017) Analysis on Supporting Policy of Small and Medium Enterprises of Science and Technology-Taking Hefei of Anhui Province as an Example. Open Journal of Social Sciences, 5, 138-152. https://doi.org/10.4236/jss.2017.54013

Received: March 2, 2017

Accepted: April 22, 2017

Published: April 25, 2017

Copyright ( 92017 by authors and Scientific Research Publishing Inc. This work is licensed under the Creative Commons Attribution International License (CC BY 4.0).

http://creativecommons.org/licenses/by/4.0/ (c) (i) Open Access

\begin{abstract}
In recent years, as the carrier of technology innovation and technology industrialization, science-technology small and medium-sized enterprises (STSME) make big contribution to transformation of scientific and technological achievements, the industrial structure optimization, the high and new technology development, innovation/entrepreneurship and increasing employment opportunities. STSME has become an important growth point of economic development. However, support policies for STSME also face many problems as policies and regulations and public service system is not perfect, poor financial ecological environment, the relative lack of scientific and technological personnel, to some extent, which hinders the development of STSME. Therefore, this article using policy text analysis method-through the extraction and analysis method of keyword network keywords to analyze policies which supports STSME in Hefei. According to the analysis results, we put forward policy recommendations.
\end{abstract}

\section{Keywords}

Small and Medium Enterprises of Science and Technology, Supporting Policies, Social Network Analysis

\section{Introduction}

With the process of global economic integration and the process of domestic supply side reform, the rapid development of STSME is becoming the main body to promote technological innovation and regional development. And so STSME plays an increasingly important role in adjusting industrial structure, promoting market prosperity and expanding social employment. 
STSME are subordinate to small and medium-sized enterprises, which are small in scale and high in flexibility. They have strong ability of scientific and technological innovation, high R \& D investment, strong enterprise growth ability and high risk and high yield, generally concentrated in the high-tech industries and strategic emerging industries in the field, once the product is recognized can bring huge gains and breakthroughs. Due to the different characteristics of STME and the different development needs of different stages of development, there are natural shortcomings in integrating internal resources and obtaining external resources. We must ensure that the technological innovation activities of enterprises are carried out smoothly by means of external forces such as government policy support. And there are many pain points in the existing support policies for STSME, such as there are some policies and regulations of the responsibility is not clear, operability is not strong, the protection of STSME is not enough, support measures cannot meet the real needs of enterprise development. We need to improve the existing policy support difficulties, and effectively for the development of STSME to provide policy help.

At present, the research on the policy of STSME at home and abroad mainly focuses on 1) Policy analysis and research, the US technology industry to promote policy analysis that the level of social education, R \& D investment increased, the strengthening of production and research cooperation can promote the development of STSME (Merchant, 1997) [1]; The results show that the supportive policies are effective in promoting the increase of the income of SME and the support policies of the SME in South Korea promote the financial performance of small and medium-sized enterprises, (Yoon, 2013) [2]. 2) the direction of the policy, that is, the US takes many measures to support STSME's development, such as the financial and taxation support policy, the innovation service organization, the information consultation and the technical service intermediary, (Ma Ji \& Wang Xinrui, 2009) [3], and proposed that the STSME should establish a platform for cooperation with the network cooperation platform, (John Bessant, 2008) [4]. Taking Jiangsu Province as an example, this paper introduces the financial support policies of STSME in Jiangsu Province, which are divided into five categories, and focuses on the experience of Jiangsu province's science and technology financial support policy, (Wu Fengju, 2015) [5]; 3) policy analysis method, putting forward a small business promotion policy according to the different aspects of policy, which is similar to the whole process of life cycle evaluation method (Vega \& Chiasson, 2015) [6]; By simulating the path of formal finance and informal finance, it is found that the strengthening of policy incentives is beneficial to increase the innovation performance of enterprises (Fan Li, 2016) [7].

According to current situation, the research mainly focuses on the experience of developed countries or the analysis of the support policies of STSME in coastal developed areas, and has less attention to policy support for STSME in underdeveloped areas. Second, the existing research is mainly based on qualitative analysis and lack of quantitative data analysis. Hefei, Anhui Province, is condu- 
cive to the development of STSME in the central, as a large province of innovation, the number of STSME increased year by year, significant economic benefits, research and development is active. As a research model of research, Hefei is very representative.

This paper uses the policy text analysis method, the keyword extraction and keyword network analysis mainly. There are four sections in full. In the first part, taking Hefei of Anhui Province as an example, this paper analyzes the supporting policies of STSME in Hefei, Anhui Province and depicting the STSME's policy map. The second part makes a textual analysis on the relevant policies of Hefei in Anhui Province, and then points out the shortcomings in the third part. In the last part of this paper, the author puts forward some suggestions on how to improve the relevant supporting policies in view of the existing problems of supporting policies, from the aspects of the adjustment of fiscal and taxation policies, the innovation of financing policy and the perfection of talent protection mechanism. This not only provides a scientific reference for the formulation of the follow-up policy of STSME in Hefei, Anhui Province, but also provides some reference for the research on the support policies of STSME in the western region, central region and other regions.

\section{STSME Supporting Policies Combing of Hefei, Anhui Province}

Since 2006, Hefei, Anhui Province, introduced a series of policies and regulations about small and medium-sized enterprises. In general, the number of these policies is on the rise, and the number of policies issued by the independent sector is greater than the number of policies developed jointly by the multisectoral sector. This chapter is the basis of this paper to sort out the support policies of small and medium-sized enterprises.

\subsection{Policy Texts Selection}

Policy text is an important form of government's rational and effective expression of policy intent. Research policy text is an effective way to explore policy makers' expression of policy intent. This paper taking the period from 2006 to 2016 in Hefei, Anhui Province government departments involved in the introduction of STSME development policy text (including some of the policies in some of the policies involved in the development of SMEs) for the study. Through the government official website, portal, public documents and other channels to obtain the 26 policy text, and we select 20 policy text finally according to the principle of openness and authority-the authority channel, the principle of timeliness-January 1, 2006 to June 30, 2016, the principle of relevance-and science and technology "small and medium enterprises", "small micro enterprises" and "private enterprises" And other topics related to the three principles.

\subsection{An Overview of Policy Texts}

1) The number of supporting policies showed a steady upward trend 
In addition to 2009, STSME supporting policies are released every year from 2006 to 2016 in Hefei, the number of policies showed a steady upward trend and reaching its peskin 2015, as shown in Figure 1. This is closely related to the central and Anhui provinces, which pay more and more attention to STSME. During the "Twelfth Five-Year Plan" period, the State Council and the central ministries and commissions have issued "Opinions on Further Promoting the Innovation and Development of STSME", "Opinions on Supporting the Healthy Development of SME" and "Interim Measures for the Administration of Special Funds for the Development of SME" And other series of policies to encourage and stimulate the development of STSME. At the same time, Anhui also introduced the "Opinions on Further Supporting the Development of SME", "Notice on Printing and Distributing the Measures for the Administration of the Construction of Small Business Enterprises in Anhui Province" and other policies to support the development of small and medium enterprises. The promulgation of these policies stimulates the introduction of the corresponding city policy of Hefei.

2) Distribution of Policy Text Enacted Agencies

The introduction of policies are often associated with the relevant government departments to participate in, and now many departments to work together to designate a policy situation has gradually become a trend. According to Table 1, we can find that the supporting policies of STSME of Hefei in Anhui Province are mainly released by a single department, less number of departments jointly promulgated the policy, and Hefei City People's Government of Anhui Province issued the largest number of STSME supporting policies., the number reached 8 , which issued 7 independent, 1 with the Communist Party of China Hefei, Anhui Province jointly issued; Followed by the Hefei Municipal People's Government Office, independently issued 5 support policies; Hefei, Anhui Province Economic and Information Technology Committee and the Hefei Finance Bureau issued 4 togetherr. In addition, the Communist Party of China Hefei, Anhui Province, Hefei, Anhui Province Science and Technology Bureau (Hefei City, Anhui Province Intellectual Property Office), Hefei, Anhui Province, financial office, the People's Bank of China Hefei Center branch are involved in the release of SME supporting policy.

The Distribution of Supporting Policies for SESME in Hefei

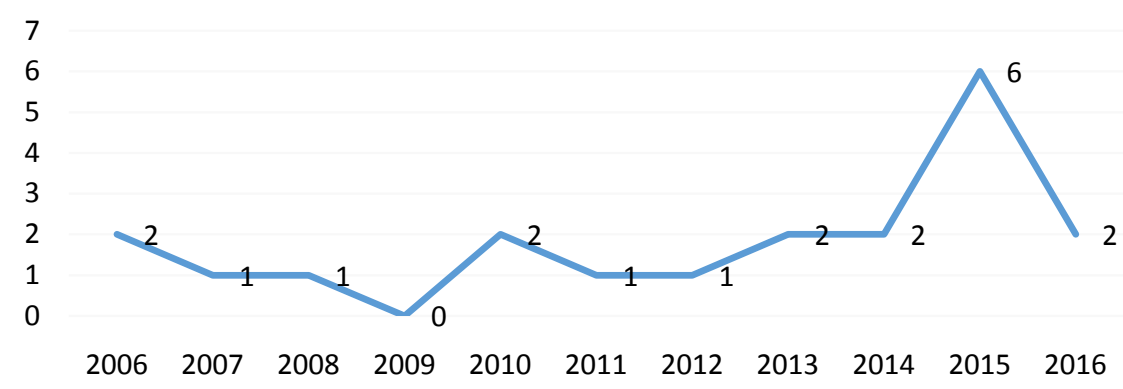

Figure 1. The Distribution of Supporting Policies for SESME in Hefei. 
Table 1. The situation of STSME Supporting Policy Enacted Agencies.

\begin{tabular}{ccccc}
\hline The form of promulgation & Issued independently & \multicolumn{2}{l}{ Issued by multiple departments } \\
\hline $\begin{array}{c}\text { Number of departments } \\
\text { involved }\end{array}$ & 1 & 2 & 3 & 4 \\
Number of policy documents & 14 & 4 & 1 & 1 \\
\hline
\end{tabular}

The template is used to format your paper and style the text. All margins, column widths, line spaces, and text fonts are prescribed; please do not alter them. You may note peculiarities. For example, the head margin in this template measures proportionately more than is customary. This measurement and others are deliberate, using specifications that anticipate your paper as one part of the entire journals, and not as an independent document. Please do not revise any of the current designations.

\subsection{Policy Text Classification}

In order to analyze the policy of supporting the development of STSME from 2006 to 2016 in Hefei, Anhui Province, this paper classifies the selected policies according to the policy terms from the perspective of policy tools. According to the existing literature (Bai et al., 2014) [8], and combination with the characteristics of SME and the contents of policies introduced, the policy clause is divided into finance and taxation, financing and guarantee, talent protection, location environment construction and management service. And so on five aspects. Some policy terms are shown in Table 2.

1) Fiscal and Taxation Policy

Financial support is an important means for the government to support STSME. The purpose of for mulatefiscal policy is mainly to encourage the development of STSME, to give financial subsidies and government procurement; Tax support mainly in order to encourage the development of SME, to create a good tax environment and give a certain tax incentives for SME.

In order to encourage the development of STSME, Hefei introduced the "Opinions on supporting the healthy development of small and micro enterprises", "On the vigorously promote the public entrepreneurship of a number of policy advice", "National Small Micro Enterprise Venture Innovation Base Urban Demonstration Action Plan (2015-2017)", And "Promotion of private economic development regulations in Hefei, Anhui Province" and other series of policy documents. To give seed-stage STSME certain tax incentives and financial subsidies, to give factory rent subsidies, and simplify the tax process, reduce the small micro-enterprise income tax rate, to extend the technical staff one-Pay the tax period and other ways to promote better and faster development of STSME.

2) Financing and Guarantee Policy

STSME's growth and innovation can not be separated from a lot of money. And the reality of financing is difficult, financing channels are long troubled enterprise development. The financial support policy promulgated in place is one of the ways to solve the financing problem of SME. 
Table 2. Situation of policies on supporting the development of SESME.

\begin{tabular}{|c|c|c|}
\hline Types & Details & Name of Source Policy \\
\hline \multirow{3}{*}{$\begin{array}{l}\text { Fiscal and } \\
\text { Taxation Policy }\end{array}$} & $\begin{array}{l}\text { To give financial and tax support to college students founded the seed } \\
\text { period of STSME, or to the outstanding project in Innovative Entre- } \\
\text { preneurship Competition. }\end{array}$ & $\begin{array}{l}\text { Opinions on supporting the healthy } \\
\text { development of SME, Hefei, Anhui Province }\end{array}$ \\
\hline & $\begin{array}{l}\text { The municipal finance give a one-time subsidy to the SME } \\
\text { whichleased standardized plant for more than a year or purchase. }\end{array}$ & $\begin{array}{l}\text { National SME innovation base city } \\
\text { demonstration action plan (2015-2017) }\end{array}$ \\
\hline & $\begin{array}{l}\text { Innovation financial products, play science and technology } \\
\text { insurance, patent pledge and other financial products, focusing on } \\
\text { supporting small and medium-sized scientific and technological de- } \\
\text { velopment. }\end{array}$ & $\begin{array}{l}\text { Opinions on supporting the healthy } \\
\text { development of SME, Hefei, Anhui Province }\end{array}$ \\
\hline \multirow[t]{3}{*}{$\begin{array}{l}\text { Financing and } \\
\text { Guarantee Policy }\end{array}$} & $\begin{array}{l}\text { Municipal financial arrangements for } 100 \text { million yuan in } 2015 \text {, to } \\
\text { establish SME switch funds to support SME; single-family business } \\
\text { loans amount of no more than } 10 \text { million yuan. }\end{array}$ & $\begin{array}{l}\text { Notice on the issuance ofSME transfer funds } \\
\text { management approach in Hefei, Anhui Province }\end{array}$ \\
\hline & $\begin{array}{l}\text { Single-family single credit line up to } 20 \text { million yuan; loan period of up } \\
\text { to } 2 \text { years (inclusive), can be used in revolving loans. }\end{array}$ & $\begin{array}{l}\text { National SME innovation base city } \\
\text { demonstration action plan (2015-2017) }\end{array}$ \\
\hline & $\begin{array}{l}\text { To establish "Great Lakes City" series of products, including "Great } \\
\text { Lakes City Growth Credit", to provide equity pledge loanto the new } \\
\text { three board, four board listed companies s. }\end{array}$ & $\begin{array}{l}\text { Great Lake city SMEto promote innovation and } \\
\text { credit products, temporary management ap- } \\
\text { proach }\end{array}$ \\
\hline \multirow[t]{2}{*}{$\begin{array}{l}\text { Talent Protection } \\
\quad \text { Policy }\end{array}$} & $\begin{array}{l}\text { Implement "thousands of industries high-end development of } \\
\text { personnel training project", "Million small micro-business } \\
\text { management personnel to enhance the project"; High-level talent team } \\
\text { can obtain up to } 10 \text { million yuan angel investment fund or } 20 \text { million } \\
\text { yuan venture capital. }\end{array}$ & $\begin{array}{l}\text { Regulations about promoting private economic } \\
\text { development in Hefei, Anhui Province }\end{array}$ \\
\hline & $\begin{array}{l}\text { Give a one-time award to SME which introduce high-level } \\
\text { management, technical personnel and special talent. }\end{array}$ & $\begin{array}{l}\text { National SME innovation base city } \\
\text { demonstration action plan (2015-2017) }\end{array}$ \\
\hline \multirow{2}{*}{$\begin{array}{l}\text { Location Environment } \\
\text { Construction }\end{array}$} & $\begin{array}{l}\text { Using idle buildings to build maker space; From the plant where the } \\
\text { government first rent back to purchase, and then through low or zero } \\
\text { rent to provide SME. }\end{array}$ & $\begin{array}{l}\text { National SME innovation base city } \\
\text { demonstration action plan (2015-2017) }\end{array}$ \\
\hline & $\begin{array}{l}\text { To establish SME service center, and to achieve the service platform of } \\
\text { interoperability, collaborative services; to build eight well-established } \\
\text { public service network platform node in the end of } 2016 \text {. }\end{array}$ & $\begin{array}{l}\text { National SME innovation base city } \\
\text { demonstration action plan (2015-2017) }\end{array}$ \\
\hline \multirow[t]{2}{*}{ Management Services } & $\begin{array}{l}\text { On the identified municipal "demonstration base", in the } \\
\text { declaration of national and provincial funding to support and } \\
\text { declare the national, provincial small micro-business demonstration } \\
\text { base, give the priority recommended. }\end{array}$ & $\begin{array}{l}\text { Interim Measures for the Determination and } \\
\text { Management of SME in Hefei, Anhui } \\
\text { Province }\end{array}$ \\
\hline & $\begin{array}{l}\text { Strengthen the construction of public service plat form, accelerate the } \\
\text { city's small and medium-sized enterprise public service } \\
\text { platform construction. }\end{array}$ & $\begin{array}{l}\text { Opinions on supporting the healthy } \\
\text { development of SME, Hefei, Anhui Province }\end{array}$ \\
\hline
\end{tabular}

te: Due to limited space, only part of the policy provisions are listed.

Hefei actively try to build a wide range of financing systems, including innovative financial products, expand financing channels, reduce the financing threshold and other forms. In the past decade, Hefei, Anhui Province, introduced the "Opinions on supporting the healthy development of SME", "Notice on the issuance of SME transfer funds management approach in Hefei, Anhui Province", "Great Lake city SME to promote innovation and credit products, temporary management approach" and "to promote private economic development regulations in Hefei, Anhui Province", and other policy documents to promote the development of SME.

The policy initiatives of Hefei, Anhui Province, including innovative financial 
products, increase the patent pledge financing, to provide high-tech enterprise product loans, the establishment of city SME lending funds, the establishment of risk compensation fund to encourage the guarantee institutions to provide loans and give financial incentives, Small and medium enterprises to loan discount, set the floating rate of lending rates, etc. Through these measures to encourage security agencies to guarantee, to stimulate bank lending, open up the SME financing channels, reduce financing costs, reduce the risk of the guarantor and lenders to solve the financing of SME.

3) Talent Protection Policy

It is difficult to protect the STSME's sound and fast development because high-tech product development, development, production and service business, and the need for specialized R \& D personnel, no high-level R \& D and management operations team. Therefore, in order to promote the introduction of scientific and technological talents, Hefei attaches great importance to the introduction of advanced technical personnel and welfare protection, they want to increase the number and quality of talent introduction through the introduction of innovative talents.

In the "national SME innovation base city demonstration action plan (20152017)", "Opinions of Hefei Municipal Committee of Anhui Province, Hefei Municipal People's Government on the development of private economy" and "Regulations about promoting private economic development in Hefei, Anhui Province" and a series of documents, Hefei have put forward some talents' measures to guarantee the development of STSME.

Specific measures include the introduction of SME to meet the requirements of the innovative business leaders, overseas high-level talent and small microenterprises to introduce high-level technical personnel, management personnel and special needs, etc., are given a one-time award, and to the introduction of talent Settlement and their children to school and employment policy support; And to take measures to select and recognize outstanding entrepreneurs, such as "thousands of industries high-end development of personnel training project", "Million small micro-business management personnel to enhance the project" [9].

4) Location Environment Construction

Location environmental construction including industrial park construction, enterprise plant or office space construction and land supply. In order to provide a good environment for the development of SME, Hefei introduced a series of policies to promote the construction of regional environment.

Including not only to use of idle factories to establish a maker space, the old plant low rent to SME, but also introduce well-known enterprises to set up maker space, incubator, allow incubator division, layered transfer and encourage upgrading and expansion the maker space within the public space and Do not change the nature of land use and so on. These policies reduce the cost of the company's rental space to a certain extent. And these policies effectively protect the rapid development of small and medium-sized micro-technology enterprises. 


\section{5) Management Services}

Hefei in order to promote the growth of STSME enterprises better, developed a number of policies to protect the efficiency of management and service and quality. These policies include "Opinions on supporting the healthy development of SME", "Interim Measures for the Determination and Management of SME in Hefei, Anhui Province", "national SME innovation base city demonstration action plan (2015-2017)", etc.

Through these policies, Hefei, Anhui Province proposed the establishment of small micro-enterprise service center, to achieve the service platform of interoperability, collaborative services, and developed the interoperability target of various services or resources by 2017; At the same time, Hefei proposed to build eight well-established public service network platform node in the end of 2016, including intellectual property, management consulting, entrepreneurship training, etc. These initiatives have contributed to the development of STSME.

\section{A Policy Analysis of the Development of STSME in Hefei, Anhui Province}

Above the introduction of support policies in Hefei, Anhui Province, the contents of the specific terms were summarized in the time distribution, the distribution of the department, and because the key information scattered in the various support policy documents throughout the space, it need a policy document conduct content analysis.

\subsection{The Extraction and Analysis of the Main Keywords of the Policy}

For a better policy content analysis, this section quantifies 20 policies for screening: Firstly, extract policy keywords related to STSME based on the principle of comprehensiveness, validity, integrity. And formed a $30 \times 30$ matrix. Then use social network visualization software analysis and we can get a STSME supporting policies' keyword network diagram of Hefei. As shown in Figure 2, the size of each node in the figure shows the focus of the support policies of small and medium-sized enterprises in Hefei, Anhui Province. The larger the nodes, the more the keywords are focused, the lines between the nodes represent the relationship strength.

\subsection{Analysis of Policy Focus}

Can be seen from the Figure 2, STSME supporting policy in Hefei presents the following characteristics: 1) tax and financial aspects of the policy, mainly reflected in the tax incentives and return, arrange special funds, research and development costs deduction, cost relief and subsidies; 2) The financial policy, it is mainly reflected in widening the financing channels, establishing risk sharing and supplementary mechanism, credit guarantee mechanism construction, strengthening credit support and enterprise credit system construction; 3) the policy of personnel protection, mainly to the introduction and training of high- 


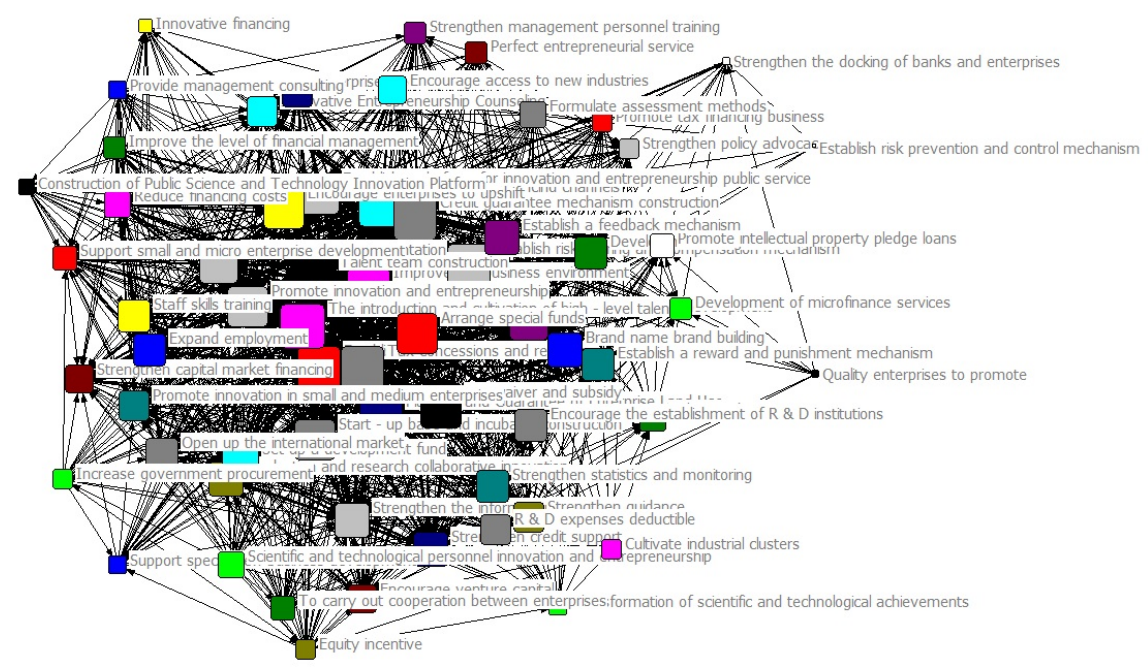

Figure 2. Supporting policy keyword relationship network diagram.

level talent, personnel and scientific and technological personnel to start innovation and entrepreneurship; 4) regional environmental construction policy, mainly to improve the business environment, enterprise land planning and protection, business base and incubator construction; 5) management services, it proposed to establish a service system and platform, innovation and entrepreneurship public service platform; also proposed to promote enterprise development, promote enterprise innovation and entrepreneurship, promote enterprises upshift, enhance the level of enterprise financial management to strengthen their own capacity construction policy.

\section{The Shortcomings of STSME Supporting Policies in Hefei, Anhui Province}

Since 2006, although the Hefei government introduced a series of policies to encourage the development of STSME and the policy effect is more obvious, there are still many shortcomings, such as the implementation of the policy Short cycle, poor stability, lack of systematic, multi-sectoral collaboration, as well as policy-oriented stage, there are still some deficiencies.

\subsection{Implementation Cycle Is Short, Policy Stability Is Weak}

In 20 STSME Supporting Policies in Hefei, most of the policy implementation cycle is one year. The policy implementation cycle can reach three years is very lacking [10]. This shows that the introduction of support policies in Hefei is weak in terms of stability. More frequent introduction of policies, making the policy coherence weakened, leading to STSME, especially seed and start-up enterprises, may have just benefited this year from a policy, but the policy suddenly stopped next year. This will reduce the enthusiasm of entrepreneurs. It may also reduce the pace of development of enterprises.

Take the financing and guarantee policy as an example, "National small micro-entrepreneur innovation base city demonstration action plan (2015-2017)" 
pointed out that to innovate financial products, and proposed to use the "Great Lakes City Council" to support enterprises only $4 \%$ of the mortgage guarantee can get no more than $20 \%$ of the benchmark interest rate loans [11], If it not introduce relevant policies after this policy expiration, STSME may be due to the small size and the lack of collateral can notobtain loans, it can not solve the problem of financing difficulties after the cancellation of this policy. Therefore, the policy of coherence is very important for the development of STSME.

\subsection{Involving More Departments, Poor Policy Coordination}

Mostly, Supporting policy in Hefei issued by independent departments, the number of policy documents issued by the joint number of departments is not much. In fact, even a single department of STSME supporting policy document itself also involves a number of departments responsibilities.

In Hefei, Anhui Province, the STSME accept Small and Medium Business Administration management. But related to financing and security and other financial aspects of the affairs, it will accept the city financial office and the Finance Bureau management; Related to intellectual property rights, technology research and development and other affairs and it will accept the Municipal Science and Technology Bureau (Municipal Intellectual Property Office) management; Involving the introduction of talent and employment and other affairs and it will accept municipal human resources and social security bureau management. The question of coordination between the various departments brought a huge challenge to policy collaboration.

\subsection{The Threshold Is High, the Policy Coverage Is Narrow}

Developed countries to support STSME is often from the universal policy to the selective support, and pay more attention to the early investigation and analysis of enterprises, according to the various stages of development and the characteristics of enterprises to develop corresponding policies and regulations [12]. Through the analysis of STSME support policies of Hefei, we found that the number of universal policy growth faster, but lack of the policy focus on the development of STSME, on the seed period STSME.

However, combined with the actual situation and predecessors of the study found that seed and start-up period of STSME need more policy support [13]. For these SME, Due to the weak technical foundation, the relative lack of research funds and R \& D personnel, coupled with the lack of fixed assets and insufficient cash flow, it is difficult to obtain funds by mortgage financing; And because the product is not stereotypes, the market uncertainty, the risk is huge, it is necessary through the government to implement the corresponding support policies to support and promote the seed period, the beginning of the development of science and technology enterprises.

In the future, Hefei want to achieve leapfrog development in the context of Double Creations, we need to increase policy efforts to promote the development of STSME. Specifically, it is necessary in the STSME life cycle at all stages, 
according to the stage characteristics and industry characteristics, to develop targeted, distinctive financial, fiscal and taxation and management services policy. Especially to increase the policy support to the seed period, start-up business, improve the viability of enterprises.

\subsection{Support System Is Not Perfect, the Policy System Is Weak}

Hefei has introduced a series of financial policies to expand the financing channels of STSME, reduce financing costs, raise the amount of financing, And through tax relief, to give financial subsidies, increase government purchases and other measures to reduce the operating costs of enterprises, and achieved certain results. However, the financing is difficult, the high cost of financing is still plagued the development of STSME. On the one hand, the establishment of STSME is short and the number of large, and the performance is difficult to assess in accordance with the traditional way, it is not easy to obtain bank loans; On the other hand, Lack of sound STSME credit assessment system, the credit level is difficult to measure.

Policy is one of the main reasons for the difficulty of financing. Due to more support policies, and often from different government departments, the general business can't understand comprehensively of the policy. In Hefei, Anhui Province, the introduction of financial policies, fiscal and taxation policies and other public service policy is not well formed to protect the good development of STSME system, it making the policy system weakened, reducing the effect of policy implementation.

\section{Suggestions on the Policy of Supporting STSME in Hefei, Anhui Province}

\subsection{Adjust Fiscal and Taxation Support Policies}

1) Increase government financial support

First of all, we should further expand the STSME Innovation and Development Fund. At present, Hefei, Anhui Province plans to set up 6 billion Yuan fund to promote small and micro enterprises innovation and entrepreneurship [14]. But the investment of funds with a large number of STSME to relatively small, Therefore, Hefei needs to combine the technological growth of SME to develop targeted financial support policies.

Secondly, to increase funding and supervision of science and technology funding. Special equipment and equipment purchase and use costs, research (development) materials and sample costs and special business costs and other three science and technology funding is a measure of urban science and technology investment in the most important indicators, but also reflects the city's innovation ability is one of the important indicators. Hefei, Anhui Province, the cost of science and technology accounted for the proportion of the city's budget is only about $2 \%$ [15]. In addition, it is necessary to increase the supervision of the three inputs of science and technology funding, clear set, fraudulent measures to deal with, and strive to play the role of each funding. 
Thirdly, increase the financial investment in key industries. Hefei, Anhui Province in the "thirteen five" plan to form a strategic emerging industries to lead the global competitive advantage of the industrial clusters, although the strategic emerging industry technology is relatively immature, the market stability is insufficient, but it has great development potential in the future. This is of great significance to the industrial upgrading and economic structural adjustment of Hefei, Anhui Province.

Finally, increase government procurement investment and supervision. Government procurement, to a certain extent, can increase business income, and accelerate the development of enterprises. Hefei, Anhui Province, while increasing the procurement of SME for science and technology, needs to further improve the transparency of the procurement process and the procurement of disputes in the relief mechanism.

2) Optimize tax subsidy policy

Hefei, Anhui Province, put forwarded the current introduction of a number of tax incentives to promote the growth of small and medium-sized science and technology enterprises. But these tax policies are mostly scattered in other policies, not enough concentration. Therefore, the government in the introduction of policy, should be combined with the characteristics of the development of small and medium-sized science and technology enterprises, improve the tax preferential policies, through the adjustment of corporate income tax, business tax, value added tax and personal income tax and other means to implement tax incentives. The specific measures include: the transformation of small and medium-sized science and technology income tax preferential way to improve the corporate income tax; targeted to improve the start-up period of small and medium-sized enterprises value-added tax; to give personal income tax concessions.

\subsection{Innovative Financial Policy}

1) Establish a sound STSME credit system

In order to systematically and comprehensively establish the credit information of STSME, it is proposed to include the enterprise credit information and electric power of relevant government functions such as industry and commerce, taxation, finance, finance, customs, quality inspection and customs on the basis of existing credit collection, Telecommunications, insurance and other service agencies involved in corporate credit information, the establishment of a unified STSME credit information platform, timely and comprehensive reflection of corporate credit, to achieve effective sharing of credit information [16]. The establishment of this platform, we need to break the government management department on the enterprise credit information block separatist management model, bar segment management is to hinder the Hefei, Anhui Province to establish a sound STSME credit information system one of the main factors.

2) Innovative financial products, rich financing model

Encourage all kinds of commercial banks and policy banks to develop targeted pledged loan products for STSME, such as equity pledge, patent pledge, trade- 
mark pledge and cash flow pledge. Through a wealth of financial products, remit the situation that the financing channels aren't smooth and financing products are single of SME. For enterprises that have obtained the above policy subsidy at the municipal level, but the funds due to the long time period of the subsidy funds are not yet in place, the Hefei Municipal Government of Anhui Province shall encourage the commercial banks to provide the loan of the nature in accordance with the formal procedures and wait for the financial subsidy funds After the timely requirements of corporate repayment, through this way to help enterprises to develop rapidly. Encourage commercial banks to innovate financial credit products according to the actual needs of STSME, simplify the approval process, and establish long-term cooperation, comprehensively understand customers, provide comprehensive credit loans and alleviate the shortage of funds for science and technology repetitive small and medium-sized enterprises.

3) Perfecting Credit Guarantee and Risk Compensation Mechanism

The sound credit guarantee system is the important financial guarantee for the rapid development of STSME enterprises [17]. Through the way of innovative credit guarantee methods, the credit incentives and constraints with the financial institutions of the loan business combine to promote the credit of good business to obtain loans. In addition, in the construction of the guarantee system, we can learn from the experience of developed countries or regions, through the government, banks, security agencies jointly funded the credit guarantee fund to absorb the comprehensive strength of the enterprise to inject capital, improve UNPROFOR credit rating and enhance the guarantee capacity.

\subsection{Optimize the Talent Protection Mechanism}

1) Increase the introduction of scientific and technological talents

Hefei, Anhui Province, should improve the introduction of relevant overseas talent policy, in particular, the Government can give a preferential policy. At the same time the use of Hefei, Anhui Province, the existing resources and relations network, increase preferential policies to promote, focusing on attracting Hefei nationality, Anhui nationality or once in Hefei school overseas talent back to fertilizer innovation and entrepreneurship, optimize the talent structure, into innovation vitality. For the domestic and provincial non-key colleges and universities of technical personnel, in the introduction of talent should reduce the bias, pay attention to the introduction of talented technology research and ability to study, do not think rigid, abandon the school good technology good idea. The introduction of domestic talent should pay attention to the technical ability of talent, professional foundation and background, pay attention to the technical staff of the practical experience.

2) Improve the social security of employees

Perfect social security system is to protect employee peace of mind, wholeheartedly rubbing into the important basis for innovation and $\mathrm{R} \& \mathrm{D}$, which is an important measure to give employees a sense of belonging to the city [18]. As 
the private enterprises of their own lack of financial strength, and give employees the relative lack of awareness of the purchase of social insurance, often overlooked the importance of social insurance for the pension insurance, medical insurance and unemployment insurance management is not standardized, coupled with the lack of effective government supervision, enterprises do not give employees to buy insurance situation has occurred, this phenomenon in the small and medium-sized enterprises in science and technology is more obvious. Therefore, the Hefei municipal government in Anhui Province if the enterprises to retain science and technology R \& D personnel, you need to guide STSME to ensure that employees of social security, the government must regulate the enterprise social security management, supervision of enterprises to buy social insurance, the policy implemented.

In recent years, STSME as one of the main carrier of innovations, play a pivotal role in promoting innovation and entrepreneurship, scientific and technological achievements and industrial structure optimization. This paper analyzes the statusquo of the development of STSME in Hefei, Anhui Province, and analyzes the existing problems from the perspective of policy text. It analyzes the existing problems and the problems in the policy. Based on the analysis results, writer raises some policy recommendations, with a certain theoretical and practical significance.

\section{References}

[1] Kang, H. and Mah, J.S. (2015) R\&D Policy for Small and Medium-Sized Enterprises in Korea. Science Technology and Society, 20, 1-20. https://doi.org/10.1177/0971721814561391

[2] Bai, Q., Cui, L. and Zhu, Y. (2014) Evolution and Evaluation of Supporting Policy on Small and Medium Technology Firms. China Science and Technology Forum, No. 8, 80-85, 91.

[3] Ma, J. and Wang, X. (2009) The US Policy Support to the SMEs' Scientific and Technological Innovation. Commercial Research, No. 05, 190-194.

[4] Cao, Y.-Y. (2016) Region Comparison on Developing Pattern and Innovation Policy of Small and Micro Scale Technological Firms. Journal of Fudan University (Social Science Edition), No. 2, 143-151.

[5] Ding, R. (2014) Study on Fiscal Policy Tools of Promoting Self-Innovation of Small and Medium Enterprises of Science and Technology in Jangsu Province. Journal of Nanjing University of Finance and Economics.

[6] Li, J. and Fan, F. (2016) Financial Synergistic Support and Policy Incentive Evaluation to Small and Mid-Sized Science and Technology Enterprises-An Empirical Study Based on B-Z Model. Journal of Tianjin University (Social Sciences Edition), 18, 11-16.

[7] Li, M. and Zhang, A.-Y. (2015) Comparison of the Motivation of Dividend Policy Selection in Small and Medium-Sized Technological Enterprises. Statistic \& Decision-Making, No. 5, 185-188.

[8] Liu, F. and Chang, S., Institute of Fiscal Science Research Group (2015) The Fiscal Policy System for Promoting the Development of Financial Services for Small and Medium-Sized Sci-Tech Enterprises. Economic Research Reference, No. 7, 33-41.

[9] Chang, L. and Xiang, H. (2014) Effects of Entrepreneurship Policy on Technolo- 
gy-Based Medium and Small Enterprises. Economics and Management Research, No. 11, 108-114.

[10] Ma, Q. (2013) The Research on the International Financing Experiences of the Small and Medium-Sized Hi-Tech Enterprises. Science and Technology Management, No. 7, 36-40.

[11] Sun, S.-L. (2016) Study on Financial Support of Chinese Science and Technology Small and Medium-Sized Enterprises. Shandong University, Jinan.

[12] Wang, J. (2012) Government to Promote Scientific and Technological Development of Small and Medium Enterprises Policy Research. Tianjin Normal University, Tianjin.

[13] Wu, J. (2012) Study on Policy Change of Technological Innovation Fund of Small and Medium-Sized Technological Enterprises Based on Policy Network. Journal of Scientific Research, No. 3, 366-371.

[14] Xia, S.P. and Ke, M.Z. (2014) A Comparative Study on the Fiscal Policy System of Innovation and Development of Small and Medium-Sized Enterprises Supporting Science and Technology at Home and Abroad. Economic Research Reference, No. 70, 34-36.

[15] Wei, X. (2015) Professor's Suggestions on Perfecting China's Tax Policy to Support Enterprise's Technological Innovation. Economic Research Reference, No. 48, 1516.

[16] Yan, L., Jiang, A. and Feng, Z. (2016) Life Cycle Characteristics and Financing Matching Analysis of Investment Value of Small and Medium-Sized Technological Enterprises. Contemporary Economic Science, No. 3, 114-123+128.

[17] Zhang, W., Lao, J. and Li, Z. (2007) Policy Support System and Stage Characteristics of China's Science and Technology Small and Medium-Sized Enterprises. Shanghai Economic Research, No. 12, 12-18.

[18] Zhang, L., Wang, P. and Liu, D.-S. (2016) Study on the Growth Factor Model of Small and Medium-Sized Technological Enterprises. Science Management Research, No. 1, 95-102.

Submit or recommend next manuscript to SCIRP and we will provide best service for you:

Accepting pre-submission inquiries through Email, Facebook, LinkedIn, Twitter, etc. A wide selection of journals (inclusive of 9 subjects, more than 200 journals)

Providing 24-hour high-quality service

User-friendly online submission system

Fair and swift peer-review system

Efficient typesetting and proofreading procedure

Display of the result of downloads and visits, as well as the number of cited articles

Maximum dissemination of your research work

Submit your manuscript at: http://papersubmission.scirp.org/

Or contact jss@scirp.org 